\title{
Antisera against epitopes resistant to denaturation on T3 (CD3) antigen can detect reactive and neoplastic T cells in paraffin embedded tissue biopsy specimens
}

\author{
D Y MASON, ${ }^{*}$ G W KRISSANSEN, $\dagger$ F R DAVEY $\ddagger$ M J CRUMPTON, $\dagger$ K C GATTER* \\ From the *Nuffield Department of Pathology, John Radcliffe Hospital, Oxford; the †Imperial Cancer Research \\ Fund, London; and the $\ddagger$ Department of Pathology, Upstate Medical Center, Syracuse, New York, USA
}

SUMMARY Polyclonal rat antisera, raised against affinity purified CD3 antigen, gave strong immunoenzymatic labelling of $T$ cells in routine paraffin embedded sections, with negligible background staining. The specificity of these reactions was confirmed by staining biopsy specimens from 21 previously phenotyped non-Hodgkin's lymphomas (including 14 of T cell origin and six of B cell origin). It is suggested that the ability of the polyclonal anti-CD3 antisera to detect T cells in paraffin sections is due to the presence in these sera of antibodies against fixation resistant epitopes on CD3 antigen, and that immunisation with purified denatured preparations of other white cell associated antigens may broaden the range of antibodies suitable for the phenotypic analysis of leucocytes in routine histological samples.

The production of monoclonal antibodies has led to the identification of several antigenic molecules associated with different white cell lineages (such as T cells, and B cells). ${ }^{1}$ These cellular markers (many of which are now well characterised at both the biochemical and DNA level) have proved of great value in clinical research; they allow white cell populations and their functions to be studied with a high degree of precision. Furthermore, many laboratories now routinely use monoclonal antibodies against human white cell antigens for the diagnosis and the characterisation of leukaemias and lymphomas.

Despite the clinical usefulness of white cell antigens a major obstacle to their wider exploitation remains in that most do not survive tissue processing - that is, formalin fixation and paraffin embedding-in a form which is detectable by most monoclonal antibodies currently available. Therefore it is usually only possible to detect white cell antigens when living cells, fresh cell smears, or sections of frozen tissue are available.

In this paper we describe the use of polyclonal antisera raised against purified denatured T3 (CD3) antigen to detect reactive and neoplastic $T$ cells in routinely processed lymphoid tissue samples. The ability to detect this well characterised $T$ cellassociated molecule in such material opens up the

Accepted for publication 26 August 1987 possibility of performing extensive retrospective studies (even when biopsy material has been stored for many years) on topics such as the prevalence of $T$ cell neoplasms in different populations and the number of $T$ cells present in reactive lymphoid infiltrates.

\section{Material and methods}

Routinely processed paraffin embedded biopsy sections were obtained from the histopathology departments of the John Radcliffe Hospital and the Upstate Medical Centre. Sections were prepared for routine histological diagnosis and then dewaxed and stained by an immunohistological procedure. All the samples of non-Hodgkin's lymphoma (with the exception of one thymoma) were selected on the basis that they had previously been immunophenotyped in cryostat sections or in cell suspension using well characterised monoclonal antibodies and techniques. ${ }^{23}$

IMMUNOHISTOLOGICAL LABELLING

Before labelling, paraffin sections were dewaxed, hydrated, and incubated with trypsin for 20 minutes as previously described. ${ }^{4}$ No staining was obtained on non-trypsinised sections. Sections were stained by the APAAP immunoalkaline phosphatase labelling procedure, ${ }^{5}$ by applying the following sequence of reagents (with intervening brief washes in Tris buffered saline): polyclonal rat anti-T3 anti- 
serum, diluted 1/100; monoclonal mouse anti-rat immunoglobulin, undiluted; rabbit anti-mouse immunoglobulin, diluted 1/20; and APAAP immune complexes, undiluted.

The last two steps were then repeated briefly (10 minutes each) and the alkaline phosphatase labelling shown by a fast red:naphthol AS-MX substrate or a hexazotised new fuchsin procedure.

\section{ANTI-CD3 ANTISERA}

The T3 (CD3) antigen was purified as described elsewhere. ${ }^{6}$ Briefly, microsomes prepared from human tonsils were solubilised in $1 \%$ Nonidet-P40, precleared with mouse IgG:Sepharose, and then adsorbed with anti-CD3 (antibody UCHT1) bound to sepharose CL-4B. Following repeated washings, adsorbed protein was eluted with $50 \mathrm{mM}$ diethylamine, $0.5 \%$ sodium deoxycholate, $\mathrm{pH} 11.5$, and lyophilised. After removal of detergent the individual CD3 polypeptides, including one of $18 \mathrm{kD}$ molecular weight, were separated by sodium dodecyl sulphate polyacrylamide gel electrophoresis (SDS-PAGE) and used to immunise Sprague-Dawley rats. ${ }^{67}$ The specificity of the antisera was analysed by Western blotting against tonsillar microsomes or affinity purified CD3 antigen after SDS-PAGE. Most of the results reported in this paper were obtained using a rat antiserum raised against the $18 \mathrm{kD}$ band which probably represented a degraded form of the $\varepsilon$ chain $(19 \mathrm{kD})$. This antiserum reacts strongly both with the $18 \mathrm{kD}$ polypeptide and with the intact $\varepsilon$ chain. ${ }^{6}$ Two other rat antisera were also used, one (raised against the denatured whole $\varepsilon$ chain), which reacts strongly with the $\varepsilon$ polypeptide and weakly with the $\delta$ chain, and a second reagent (raised against the denatured $\delta$ chain) which reacts strongly with both the $\delta$ and $\varepsilon \overrightarrow{\overline{\vec{N}}}$ chains.

\section{Results}

NON-NEOPLASTIC TISSUE

When paraffin embedded sections from a variety of ${ }^{\infty}$ biopsy specimens containing reactive $T$ cells (lymph $\vec{\circ}$ node, skin, ileum) were stained with the anti-CD3 $\overrightarrow{\vec{H}}$ antiserum all gave strong staining of cells of lymphoid ${ }_{\sigma}^{\omega}$ morphology. T cell areas of lymphoid tissue showed 홍 extensive staining contrasting with B cell follicles (fig 1) in which the only positive cells were scattered small $\vec{\sim}$ lymphoid cells, presumably reactive $T$ cells. The staining patterns on normal tissue were essentially ${ }_{-}$ identical with those seen in cryostat sections of the 0 same type of biopsy sample. In paraffin sections of ${ }_{-}$ normal thymus anti-CD3 antisera gave strong staining 7 of lymphoid cells in both the medulla and cortex (fig 2).

A range of normal human tissues was analysed with the anti-CD3 antiserum for evidence of staining of $\overrightarrow{0}$ non-lymphoid cells. Such reactions were absent or ${ }_{\infty}^{\infty}$ very weak, with the exception of squamous epithelium which tended (principally in epidermis and Hassall'so corpuscles) to show weak diffuse cytoplasmic staining. Non-lymphoid cells did not show the peripheral ring-o like pattern of membrane staining seen on normal $T \stackrel{0}{\mathbb{D}}$ cells.

Table Immunohistological reactivity of polyclonal anti-CD3 antiserum on 21 paraffin embedded non-Hodgkin's lymphomas

\begin{tabular}{|c|c|c|c|c|}
\hline & $\begin{array}{l}\text { Histological type } \\
T \text { cell neoplasms: }\end{array}$ & \multicolumn{2}{|c|}{ Phenotype (fresh tissue) } & Reactivity with polyclonal anti-CD3 \\
\hline $\begin{array}{r}1 \\
2 \\
3 \\
4 \\
5 \\
6 \\
7 \\
8 \\
9 \\
10 \\
11 \\
12 \\
13 \\
14\end{array}$ & $\begin{array}{l}\text { T cell neoplasms: } \\
\text { Thymoma } \\
\text { Lymphocytic } \\
\text { Mycosis fungoides } \\
\text { Lennert's lymphoma } \\
\text { Lymphoblastic } \\
\text { Lymphoblastic } \\
\text { Lymphoblastic } \\
\text { Lymphoblastic } \\
\text { Lymphoblastic } \\
\text { Lymphoblastic } \\
\text { Large cell lymphoma } \\
\text { Large cell lymphoma } \\
\text { Large cell lymphoma } \\
\text { "Malignant histiocytosis" of the intestine (MHI) }\end{array}$ & $\begin{array}{l}\text { CD3 } \\
\text { NT } \\
\text { Positive } \\
\text { Positive } \\
\text { Positive } \\
\text { Positive } \\
\text { Positive } \\
\text { Positive } \\
\text { ND } \\
\text { Negative } \\
\text { Positive } \\
\text { Positive } \\
\text { Positive } \\
\text { Positive } \\
\text { Negative }\end{array}$ & $\begin{array}{l}\text { CD4/CD8 } \\
\text { NT } \\
\text { CD4 } \\
\text { CD8 } \\
\text { NT } \\
\text { CD8 } \\
\text { CD8 } \\
\text { Negative } \\
\text { Negative } \\
\text { Negative } \\
\text { CD4 + CD8 } \\
\text { Negative } \\
\text { Negative } \\
\text { Negative } \\
\text { Negative }\end{array}$ & $\begin{array}{l}\text { Positive } \\
\text { Positive } \\
\text { Positive } \\
\text { Positive } \\
\text { Positive } \\
\text { Positive } \\
\text { Positive } \\
\text { Positive } \\
\text { Positive } \\
\text { Positive } \\
\text { Positive } \\
\text { Positive } \\
\text { Positive } \\
\text { Negative }\end{array}$ \\
\hline $\begin{array}{l}15 \\
16 \\
17 \\
18 \\
19 \\
20\end{array}$ & $\begin{array}{l}\text { B cell neoplasms: } \\
\text { Centroblastic } \\
\text { Centroblastic } \\
\text { Centroblastic, centrocytic } \\
\text { Large cell } \\
\text { Immunoblastic } \\
\text { Myeloma }\end{array}$ & $\begin{array}{l}C D 3 \\
\text { Negative } \\
\text { Negative } \\
\text { Negative } \\
\text { Negative } \\
\text { Negative } \\
\text { Negative }\end{array}$ & $\begin{array}{l}\text { CDI } 9 / 22 \\
\text { Positive } \\
\text { Positive } \\
\text { Positive } \\
\text { Positive } \\
\text { Negative } \\
\text { Negative }\end{array}$ & $\begin{array}{l}\text { Negative } \\
\text { Negative } \\
\text { Negative } \\
\text { Negative } \\
\text { Negative } \\
\text { Negative }\end{array}$ \\
\hline 21 & $\begin{array}{l}\text { Unclassified: } \\
\text { Pleomorphic large cell (Ki-1 lymphoma) }\end{array}$ & Negative & Negative & Negative \\
\hline
\end{tabular}

Positive and negative refers to the labelling reactions of the neoplastic cells: in all cases scored as negative strongly reactive normal lymphocytes were present. 

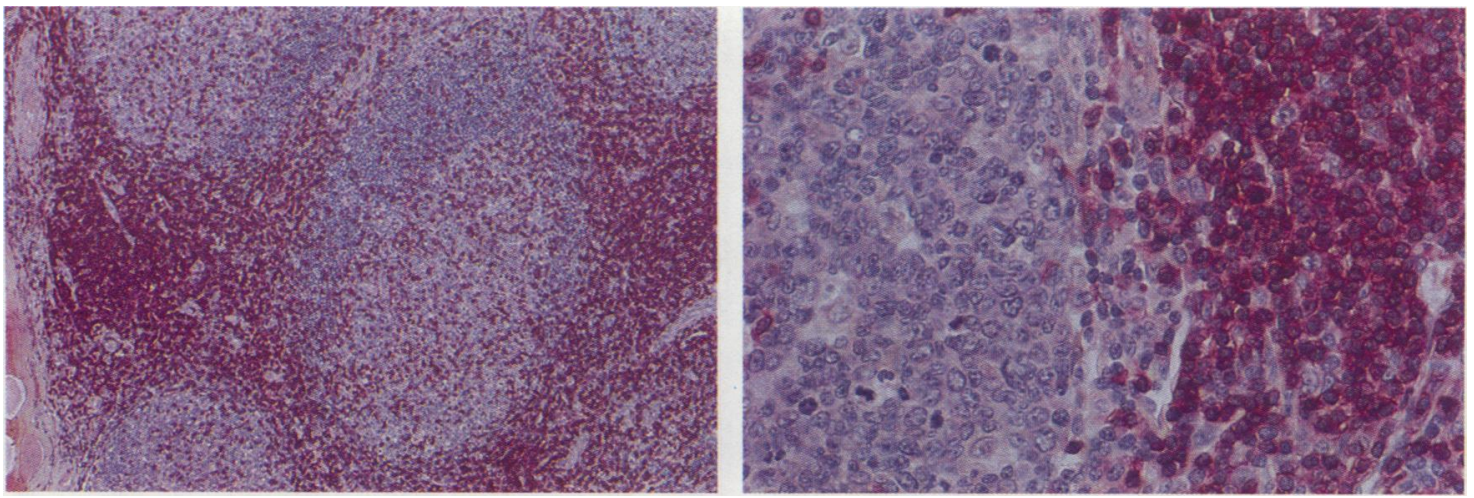

Fig 1 Tonsil: (a) strong staining of $T$ cell areas and of scattered $T$ cells in B cell follicles. (b) High power view of same tissue showing clear contrast between strongly labelled $T$ cells and adjacent unstained $B$ cells in germinal centre.

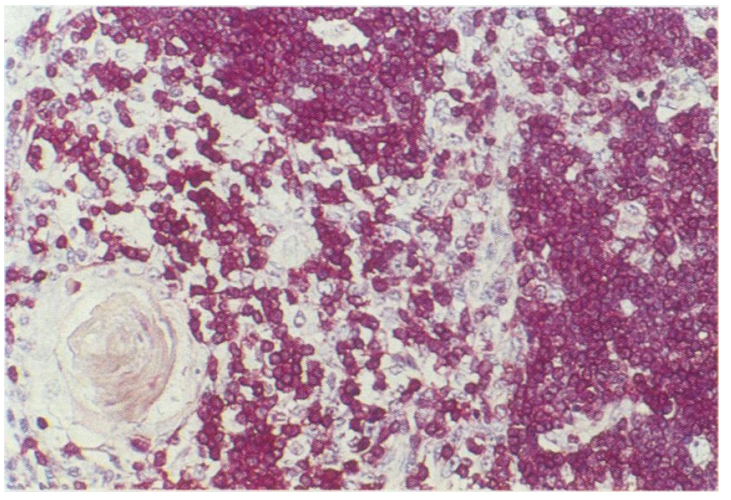

Fig 2 Thymus: strongly labelled thymocytes in cortex (to the right and above) and, more sparsely distributed, in medulla. Note unstained Hassall's corpuscle.

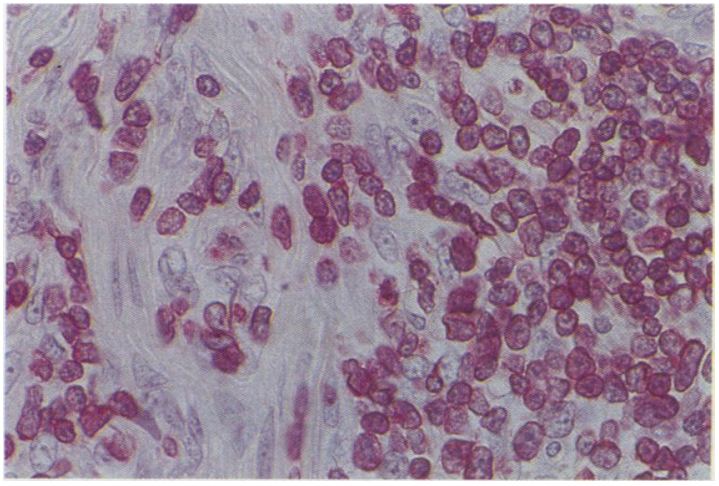

Fig 3 Thymoma: note contrast between strongly stained neoplastic $T$ cells and unlabelled epithelial elements in tumour.

\section{LYMPHOID NEOPLASMS}

A total of 21 routine paraffin embedded biopsy specimens from previously phenotyped lymphomas were analysed. The results are summarised in the table (figs 3-6).

Phenotyping of fresh tissue was performed on cryostat sections with the exception of cases 7 to 11 , which were all phenotyped in cell suspension by surface fluorescence. Classification as $\mathrm{T}$ or $\mathrm{B}$ cell neoplasms was based on reactivity with a panel of monoclonal antibodies against well established CD antigens, but only data for CD3, CD4, CD8, CD19 and $\mathrm{CD} 22$ are included in the table.

Case 14 was classified as a $T$ cell neoplasm on the basis of phenotype and $T$ cell receptor gene rearrangement. Case 19 was classified as B cell immunoblastic lymphoma on the grounds of morphology and negativity for $\mathrm{CD} 3,4$, and 8 . It was negative for the CD22 B cell marker and was not tested for the pan-B marker CD19.

The anti-CD3 antiserum labelled neoplastic cells in all cases of previously assigned CD3 positive lymphoma. In contrast, B cell and null cell neoplasms gave negative reactions. In some cases of $\mathrm{T}$ lymphoblastic lymphoma the neoplastic cells seemed to contain CD3 antigen in the perinuclear space (fig 5). In one case of large cell lymphoma of $\mathrm{T}$ cell type CD3 positive intracellular inclusions seemed to be present in a few of the neoplastic cells.

\section{Discussion}

The results indicate that polyclonal antisera against the purified, denatured, individual polypeptides of the CD3 antigen can be used, by immunoenzymatic staining, to show $T$ cells in routinely processed paraffin embedded human tissue samples. Of particular note is the high intensity of labelling obtained, associated 

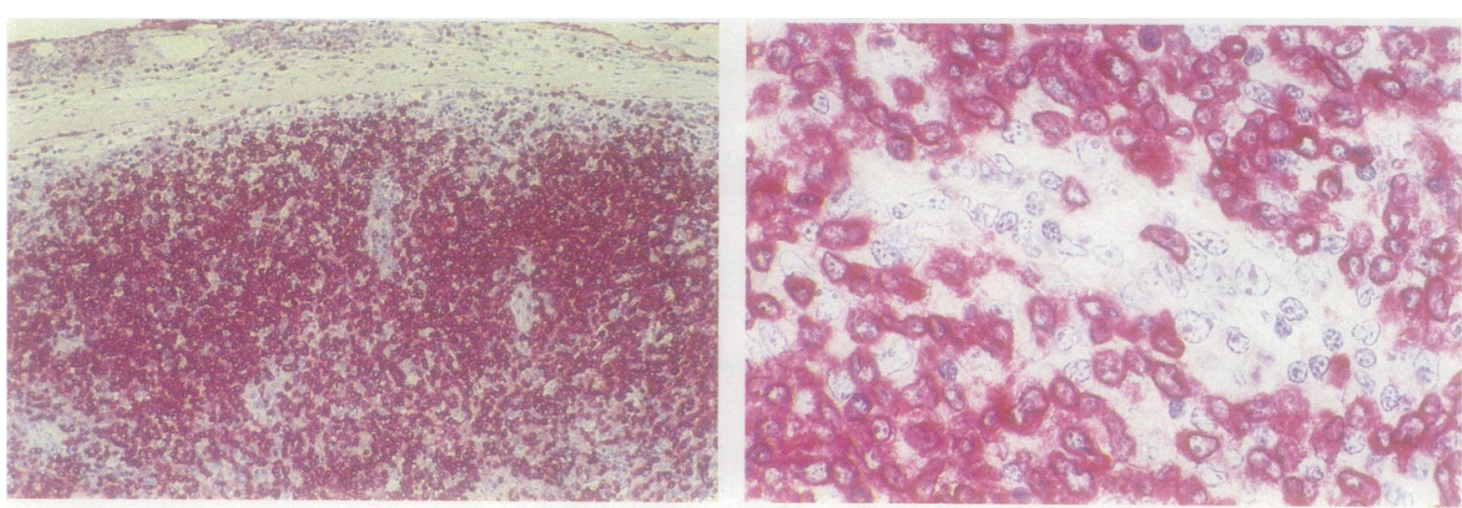

Fig $4 T$ cell lymphoma (large cell): (a) extensive staining of neoplastic cells. Note unlabelled vessels; (b) high power view of $\stackrel{\vec{\Delta}}{\dot{n}}$ one of these vessels.

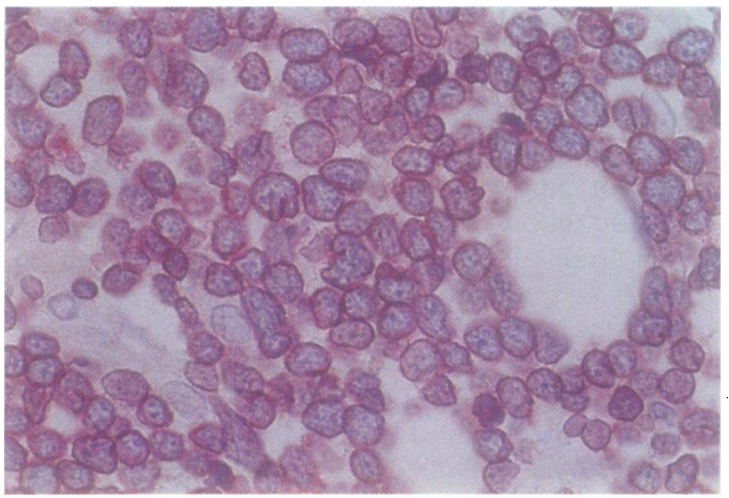

Fig 5 T cell lymphoma (lymphoblastic): labelling for CD3 antigen outlines the nuclear periphery in the neoplastic cells. Indented nuclear profile of several cells is clearly seen.

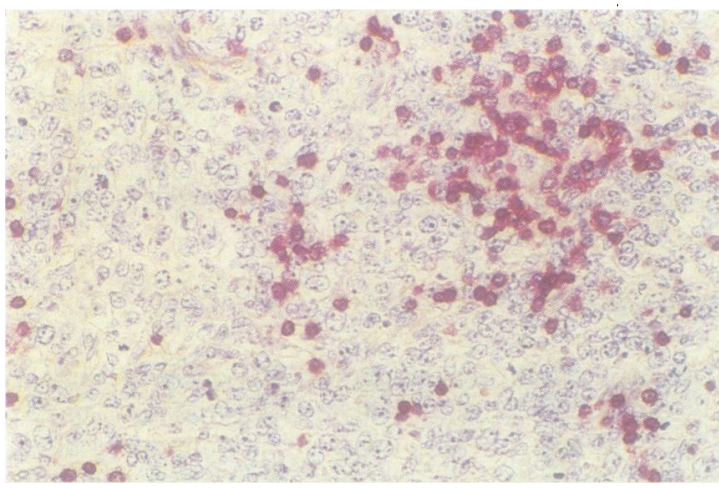

Fig 6 B cell lymphoma (centroblastic): scattered reactive $T$ cells are seen among unstained neoplastic cells. with minimal non-specific background staining. The 윽 ability to identify normal and neoplastic $T$ cells $\vec{T}$ specifically in paraffin sections is of considerable $\mathbb{T}$ practical importance for two reasons. Firstly, the morphological preservation of cellular detail in this type of material is clearly superior to that seen in cryostat sections. Consequently it may now be $\odot$ possible to undertake immunohistological studies 9 which have previously been hampered by the poor $\square$ preservation of morphological detail in cryostat sections (such as on the T cell nature of Reed Sternberg cells). Secondly, the possibility arises of extensive retrospective studies of reactive and neoplastic T cell $\stackrel{\square}{\square}$ populations in stored tissue blocks.

There have been several reports of monoclonal antibodies capable of detecting $T$ cells in routinely $\vec{P}$ processed paraffin embedded tissue. ${ }^{8-13}$ The best characterised of these reagents (in terms of the target antigen) is antibody UCHLl, which recognises the T $?$ cell-associated variant of the leucocyte common $\frac{5}{3}$ antigen. ${ }^{8914}$ Although the antibody reacts with most $\mathrm{T} \stackrel{3}{\mathrm{~S}}$ cells, it also recognises a minor population of B cells $O$ (and also some histiocytes). In keeping with this pattern of reactivity, it has been shown to detect not $\frac{\text { 의 }}{2}$ only most $\mathrm{T}$ cell lymphomas, but also some $\mathrm{B}$ cell $\rightarrow$ neoplasms. ${ }^{912}$ Another reagent which may be similar to UCHL1 is monoclonal antibody MTl, which was $N$ reported by the laboratory from which it originated to recognise a $190 \mathrm{kD}$ antigen." "13 Although this 0 molecular weight is appropriate for the $T$ cell- $\mathrm{W}$ associated variant of the leucocyte common antigen, antibody MT1 (unlike UCHL1) has not been investi- 0 gated in any of the workshops on leucocyte differentiation antigens and its specificity for this molecule $\stackrel{?}{?}$ remains unproved, but it resembles antibody UCHL1 in that it reacts with proportion of B cell neoplasms."

In contrast to these reagents, the polyclonal antisera $\stackrel{\odot}{\mathcal{P}}$ reported in the present paper react with an antigen $\stackrel{\varnothing}{\varrho}$ 
(CD3) which in the course of extensive analyses has never been found on B cells. The antigen was first detected more than seven years ago and was given the designation CD3 at the first international workshop on human leucocyte differentiation antigens in $1983,{ }^{\text {is }}$ although it is also widely referred to as "T3 antigen", after the name of the first reported monoclonal antiCD3 antibody. ${ }^{16}$

The CD3 antigen seems to be unique to the $T$ cell lineage. The only possible exception is its reported weak expression in Purkinje cells in the brain ${ }^{17}$; but within haemopoietic and lymphoid tissue there is no evidence for the molecule's existence on any cells other that those of $\mathrm{T}$ lymphoid origin. It appears early in $\mathrm{T}$ cell maturation, initially within the perinuclear space (at the precortical thymocyte stage) ${ }^{18}$ and then subsequently, in post-cortical $T$ cells in the cell surface membrane. It has been suggested that the appearance of small amounts of intracellular CD3 indicates the earliest sign of committment to the $\mathrm{T}$ cell lineage. ${ }^{19} \mathrm{The}$ $\mathrm{T}$ cell lymphomas in this study, in which CD3 antigen appeared to be localised around the cell nucleus, may therefore have arisen from early stages of $T$ cell maturation (while the case showing probable CD3 inclusion bodies may reflect a block in the insertion of the antigen in the surface membrane).

Biochemical studies have shown that the CD3 antigen consists of at least three polypeptide chains. These are designated $\gamma, \delta$, and $\varepsilon$, having molecular weights of 26,21 , and $19 \mathrm{kD}$ respectively. ${ }^{201}$ Genes coding for each of these chains have now been identified, ${ }^{722}{ }^{23}$ and it is evident that whereas the $\gamma$ and $\delta$ chains show considerable homology to each other in their amino acid sequences, the $\varepsilon$ chain shows a much more remote association. ' Additional chains in the human $\mathrm{CD} 3$ complex may also be recognised as the T3 antigen in mice apparently comprises at least five different polypeptide chains - that is, three chains equivalent to the human $\gamma, \delta$, and $\varepsilon$ chains, plus additional 21 and $16 \mathrm{kD}$ chains. ${ }^{24}$ There has been a recent report claiming to identify the human equivalent of the $16 \mathrm{kD}$ chain. ${ }^{25}$ The $\mathrm{CD} 3$ polypeptide chains are closely associated in the $T$ cell membrane not only with each other, but also with the $T$ cell antigen receptor. ${ }^{26}$ It is likely that $\mathrm{CD} 3$ plays a crucial part in the response of $\mathrm{T}$ cells to antigenic stimuli by delivering a biochemical signal to the cell interior following binding of antigen to the receptor.$^{25}$ In this context it may be of relevance that stimulation of $T$ cells by specific antigen, polyclonal mitogens, or phorbol ester causes rapid selective phosphorylation, especially of the $\gamma$ chain of the CD3 complex. ${ }^{27} 28$

Previous studies of fresh cell and tissue samples have indicated that the CD3 antigen is present on many $T$ cell neoplasms. ${ }^{1729-31}$ In keeping with the fact that it is initially an internal cell constituent its demonstration in leukaemias and lymphomas of thymic phenotype requires a technique which shows intracellular antigen, such as staining of cytospin preparations or tissue sections. ${ }^{32}$ In the present study this phenomenon is probably epitomised by the lymphoblastic lymphoma (case 9) which was CD3 negative when tested in cell suspension, but strongly positive when stained in paraffin sections.

The specificity of the CD3 antigen for the T cell lineage and its appearance very early in $\mathrm{T}$ cell maturation make it an obvious candidate as an optimal pan- $T$ marker for detecting $T$ cell neoplasms. No laboratories, however, have previously convincingly shown that the antigen can be detected reliably in formalin fixed paraffin embedded tissue. It must therefore be concluded that most, if not all, existing monoclonal anti-CD3 antibodies recognise epitopes which are destroyed by tissue processing. In keeping with this we have found, when screening 20 antibodies of this specificity from the third international workshop on human leucocyte differentiation antigens, that none of these reagents was capable of staining routinely processed paraffin embedded lymphoid tissue.

The strong labelling for CD3 obtained in the present study suggests that the polyclonal CD3 antisera contained antibodies directed against epitopes of the CD3 complex resistant to denaturation. It may be relevant that the antisera were raised against isolated CD3 chains which had been purified from lymphocyte membranes by immunoaffinity chromatography and subsequent elution after SDS-PAGE of the purified antigen. The antisera thus differ from existing monoclonal CD3 antibodies, most, if not all, of which were raised against living or lightly fixed $\mathrm{T}$ cells. Exposure of the CD3 antigen to denaturing agents (high $\mathrm{pH}$, SDS) during its isolation may expose or induce epitopes which are not found in the native molecule, but which are present in formalin fixed tissue sections. In this case a proportion of the anti-CD3 antibodies in the polyclonal antisera would be expected to recognise these epitopes. This hypothesis is supported by the fact that the anti-CD3 antisera gave strong reactions by Western blotting as well as on paraffin sections but showed negligible reactivity when tested against living $T$ cells (in which all epitopes would be in the native conformation) (Krissansen G, unpublished observation). This discrepancy might also be accounted for, at least in part, by the presence in the polyclonal antisera of a predominance of antibodies specific for intracytoplasmic portions of the CD3 polypeptides (which would not be accessible on the surface of whole cells).

While the antiserum raised against the denatured $\delta$ chain recognised this chain, it also possessed a strong reactivity with the $\varepsilon$ chain. Furthermore, as the anti-18 $\mathrm{kD}$ serum is specific for the $18 \mathrm{kD}$ and $\varepsilon$ chains, the 
epitope(s) resistant to denaturation are probably an inherent feature of the $\varepsilon$ chain. Interestingly, the cytoplasmic domain of the $\varepsilon$ chain would be anticipated to possess an unfolded structure as it is rich in glycine and proline residues and likely to be relatively resistant to denaturation.

Finally, the present study is of potentially much wider relevance than in the context of $\mathrm{CD} 3$ antigen alone, as it raises the possibility of detecting denaturation resistant epitopes on other well characterised molecules specific for different white cell lineages-for example, CD4, CD5, CD8, CD19, CD22, etc-and thereby greatly widening the scope of immunocytochemistry in the study of routine histological material. This is particularly relevant in the typing of $T$ cell neoplasms as CD3, although a reliable member of early $\mathrm{T}$ cells, is absent on up to $20 \%$ of post-thymic $\mathrm{T}$ cell lymphomas. ${ }^{30} 3133$ An effective strategy for the production of such reagents is likely to be immunisation of animals with purified antigen that has been deliberately denatured during isolation so as to increase the likelihood of producing antibodies against determinants which resist tissue processing. It will also be of value to produce monoclonal antibodies which duplicate the specificity of the polyclonal antiCD3 antisera described in this paper. This would ensure the reproducibility of reagents for detecting CD3 in routine biopsy specimens, facilitate their large scale production, and avoid the weak non-specific staining reactions-for example, of squamous epithelium-associated with the present polyclonal antisera.

This work was supported by grants from the Leukaemia Research Fund and the Wellcome Trust. We are grateful to Margaret Jones for skilful technical assistance, Andrea Houghton and Bridget Watson for preparation of this manuscript, Dr D W Mason for generously providing monoclonal mouse antirat $\mathrm{Ig}$ antibody; Winston Verbi for valuable help in the purification of the CD3 antigen, and to the different hospitals in the Greater London area who provided tonsil samples for this purpose.

\section{References}

1 Reinherz EL, Haynes BF, Nadler LM, Bernstein ID. Leucocyte typing II. New York: Springer Verlag, 1986.

2 Gatter KC, Falini B, Mason DY. The use of monoclonal antibodies in histopathological diagnosis. In: Anthony $\mathbf{P}$, MacSween R, eds. Recent advances in histopathology. Vol 12. Edinburgh: Churchill Livingstone, 1984:35-67.

3 Stein H, Mason DY. Immunological analysis of tissue sections in diagnosis of lymphoma. In: Hoffbrand AV, ed. Recent advances in haematology 4. Edinburgh: Churchill Livingstone, 1985: $127-69$.

4 Mepham BL, Frater W, Mitchell BS. The use of proteolytic enzymes to improve immunoglobulin staining by the PAP technique. Histochem J 1979;11:345-57.

5 Mason DY. Immunocytochemical labelling of monoclonal antibodies by the APAAP immunoalkaline phosphatase technique. In: Bullock G, Petrusz P, eds. Techniques in immunocyto- $\overrightarrow{\vec{T}}$ chemistry. Vol 3. London: Academic Press, 1985:25-42.

6 Krissansen GW, Verbi W, Totty NF, Crumpton MJ. Purification and identification by amino acid sequence analysis of the $\bar{\sigma}$ subunits of the CD3 antigen of human tonsil T-lymphocytes. $\overline{\bar{\omega}}$ Mol Immunol 1987;24:1069-79.

7 Krissansen GW, Owen MJ, Verbi W, Crumpton MJ. Primary $\stackrel{\mathbb{Q}}{\varrho}$ structure of the T3 $\gamma$ subunit of the T3/T cell antigen receptor $\infty$ complex deduced from cDNA sequences: evolution of the T3 $\gamma$ and $\delta$ subunits. EMBO J 1986;5:1799-808.

8 Smith SH, Brown MH, Rowe D, Callard RE, Beverley PCL. Functional subsets of human help-inducer cells defined by a new $\vec{\omega}$ monoclonal antibody, UCHLI. Immunology 1986;58:63-70.

9 Norton AJ, Ramsay AD, Smith SH, Beverley PCL, Isaacson PG.융 Monoclonal antibody (UCHL1) that recognises normal neo-? plastic $T$ cells in routinely fixed tissues. J Clin Pathol 1986; 39:399-405.

10 Norton AJ, Isaacson PG. An immunocytochemical study of T-cell $\vec{N}$

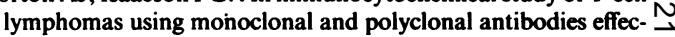
tive in routjnely fixed wax embedded tissues. Histopathology $\mathrm{O}$ 1986;10:1243-60.

11 Poppema S, Hollema H, Visser L, Vos H. Monoclonal antibodies $\vec{T}$ (MT1, MT2, MB1, MB2, MB3) reactive with lymphocyte $\mathbb{( D}$ subsets in paraffin embedded tissue sections. Am $J$ Pathol 1987;127:418-29.

12 Davey FR, Gatter KC, Ralfkiaer E, Pulford KAF, Krissansen GW, Mason DY. Immunophenotyping of non-Hodgkin's lymphoma using a panel of antibodies on paraffin embedded $\vec{C}$ tissues. Am J Pathol 1987;129:54-65:

13 Hall PA, d'Ardenne AJ, Butler MG, Habeshaw JR, Stansfeld AG. New marker of B lymphocytes MB2: comparison with other lymphocyte subset markers active in conventionally processed tissue sections. J Clin Pathol 1987;40:151-6.

14 Hale G, Stafford C, Lovat O, Prospero T, Waldmann H. Epitope mapping of the human leucocyte common antigen. In: McMichael A, et al, eds. Leucocyte typing III. Oxford: Oxford $\varrho$ University Press, 1987 (in press).

15 Bernard A, Boumsell $L$, Hill C. Joint report of the First $\frac{\text { 의 }}{3}$ International Workshop on Human Leucocyte Differentiation Antigens by the investigators of the participating laboratories. In: Bernard A, et al, eds. Leucocyte typing. New York: Springer? Verlag, 1984:9-142.

16 Kung PC, Goldstein G, Reinherz EL, Schlossman SF. Mono-용 clonal antibodies defining distinctive human $T$ cell surface $\bar{O}$ antigens. Science 1979;206:347-9.

17 Garson JA, Beverley PCL, Coakham HB, Harper EL. Monoclonal antibodies against human T-lymphocytes label Purkinje $O$ neurons of many species. Nature 1982;298:375-7.

18 Furley AJ, Mizutani S, Wellbeacher K, et al. Developmentally응 regulated rearrangement and expression of genes encoding the $T$ cell receptor-T3 complex. Cell 1986;46:75-87.

19 Campana D, Thompson JS, Amlot P, Brown S, Janossy G. The cytoplasmic expression of CD3 antigens in normal and malig- $N$ nant cells of the $T$ lymphoid lineage. $J$ Immunol 1987;138:O 648-55.

20 Kanellopoullos JM, Wigglesworth NM, Owen MJ, Crumpton MJ. Biosynthesis and molecular nature of the T3 antigen of $\omega$ human T lymphocytes. EMBO J 1983;2:1807-14.

21 Borst J, Alexander S, Elder J, Terhorst C. The T3 complex on human $\mathrm{T}$ lymphocytes involves four structurally distinct glycoproteins. J Biol Chem 1983;258:5135-41.

22 Van den Elsen P, Shepley BA, Borst J, et al. Isolation of cDNA? clones encoding the 20k T3 glycoprotein of human T-cell $T$ receptor complex. Nature 1984;312:413-8.

23 Gold DP, Puck JM, Pettey CL, Cho M, Coligan J, Woody JN. Isolation of cDNA clones encoding the $20 \mathrm{kD}$ non-glycosylated $\frac{\widehat{P}}{\Phi}$ polypeptide chain of human T-cell receptor/T3 complex. Nature $\mathrm{Q}$ 
1986;321:431-4.

24 Samelson LE, Harford JB, Klausner RD. Identification of the components of the murine $\mathrm{T}$ cell antigen receptor complex. Cell 1985;43:223-1.

25 Weissman AM, Samelson LE, Klausner RD. A new subunit of the human T-cell antigen receptor complex. Nature 1986;324: 480-2.

26 Brenner MB, Trowbridge IS, Strominger JL. Cross-linking of human $T$ cell receptor proteins: association between the $T$ cell idiotype subunit and the T3 glycoprotein heavy subunit. Cell 1985;40:183-90.

27 Samelson LE, Patel MD, Weissman AM, Harford JB, Klausner RD. Antigen activation of murine $T$ cell induces tyrosine phosphorylation of a polypeptide associated with the $\mathrm{T}$ cell antigen receptor. Cell 1986;46:1083-90.

28 Cantrell DA, Davies AA, Crumpton MJ. Activators of protein kinase $C$ down regulate and phosphorylate the $T 3 / T$ cell antigen receptor complex of human T-lymphocytes. Proc Natl Acad Sci USA 1985;82:8158-62.

29 Erber WN, Mynheer LC, Mason DY. APAAP labelling of blood and bone-marrow samples for phenotyping leukaemia. Lancet 1986;i:761-5.

30 Grogan TM, Fielder K, Rangel C, et al. Peripheral T-cell lymphoma: aggressive disease with heterogeneous immunotypes. Am J Clin Pathol 1985;83:279-88.

31 Weiss LM, Crabtree GS, Rouse RV, Warnke RA. Morphologic and immunologic characterization of 50 peripheral $\mathrm{T}$ cell lymphomas. Am J Pathol 1985;118:316-24.

32 Link MP, Stewart SJ, Warnke RA, Levy R. Discordance between surface and cytoplasmic expression of the Leu-4 (T3) antigen in thymocytes and in blast cells from childhood $\mathrm{T}$ lymphoblastic malignancies. J Clin Invest 1985;76:248-53.

33 Picker LJ, Weiss LM, Medeiros LJ, Wood GS, Warnke RA Immunophenotypic criteria for the diagnosis of non-Hodgkin's lymphoma. Am J Pathol 1987;128:181-201.

Requests for reprints to: Dr D Y Mason, Nuffield Department of Pathology, John Radcliffe Hospital, Oxford OX3 9DU, England. 